\title{
A BODIPY-PHENOL-BASED SENSOR FOR SELECTIVELY RECOGNIZING THREE BASIC ANIONS
}

\author{
YONGJUN LV $V^{a, b *}$, WEI WEI ${ }^{a}$, and YUNTAO XIE ${ }^{a}$ \\ a. College of Material and Chemical Engineering, Sichuan University of Science and Engineering, Zigong 643000, Sichuan Province, P.R. China \\ ${ }^{b}$. Key Laboratories of Fine Chemicals and Surfactants in Sichuan Provincial Universities, Zigong 643000, Sichuan Province, P.R. China
}

\begin{abstract}
A novel BODIPY-based anion sensor $\mathbf{1}$ bearing di-tert-butyl phenol unit was designed and prepared. In the presence of three basic anions $\mathrm{F}^{-}$, $\mathrm{AcO}^{-}$or $\mathrm{H}_{2} \mathrm{PO}_{4}^{-}$, $\mathbf{1}$ exhibited two novel partially overlapped red-shift absorption bands at $718 \mathrm{~nm}$ and $757 \mathrm{~nm}$, respectively. The formation of allotropic structures, after deprotonation of phenol $\mathrm{OH}$, is responsible for these two emerging bands. Fluorescence quenching was also observed due to intramolecular charge transfer (ICT) from phenolate to BODIPY core. As results revealed, the anion affinity mainly depended on the acidity of binding site $\mathrm{OH}$ and the basicity of the target anion. Moreover, two bulky tert-butyl groups cannot effectively exclude the approach of large anions to phenol $\mathrm{OH}$, but can facilitate the formation of allotropic resonance structures.
\end{abstract}

Keywords: BODIPY, phenol, anion sensor, deprotonation, steric effect

\section{INTRODUCTION}

Currently, the development of optical anion sensors is an active research area of paramount significance in supramolecular chemistry ${ }^{1-6}$. In particular, phenol-based anion chemosensors have garnered considerable attention in the last decades, because phenol $\mathrm{OH}$ can act as an anion receptor through hydrogen bonding or deprotonation ${ }^{7-13}$. These chemosensors are generally chromogenic and/or fluorescent probes, which efficiently change their photophysical properties in the presence of anions. Among numerous fluorophores, BODIPY dyes possess excellent photophysical properties and applications in the areas of anion sensors, metal probes, and $\mathrm{pH}$ indicators ${ }^{14-20}$. This versatile utility is due to the capacity to substitute the many positions of the BODIPY core in Figure 1. Recent reviews have enumerated a number of peripheral BODIPY substituents acting as various sensors based on Photoinduced electon transfer (PET) and intramolecular charge transfer (ICT) mechanisms. In general, C(8)substituent BODIPY perform a standard green emitting PET fluorophore, while vinyl C(3)-substituent derivatives represent a longer wavelength absorbing and red emitting ICT fluorophore. In previous work, we have reported PET anion sensors $\mathbf{3}$ and $\mathbf{4}$ with phenol unit at the C(8)-position of BODIPY core in Figure $1^{21}$. Where 3 shows the special selectivity for $\mathrm{F}^{-}$through color change and fluorescence quenching, the hindrance of tert-butyl groups and the fitness of Brønsted acid-base are responsible for selective $\mathrm{F}^{-}$recognition over other tested anions. To our knowledge, both PET and ICT processes could lead to different optical output ${ }^{22,23}$. We therefore wonder if phenol unit can be introduced at C(3)-position of BODPIY by a vinyl spacer to acquire an ICT-based anion sensor. In this report, we synthesized two BODIPY-phenol derivatives $\mathbf{1}$ and $\mathbf{2}$ according to the route illustrated in Figure 1. The large bulky tert-butyl groups were introduced to tune the acidity and the anion affinity of phenolic $\mathrm{OH}$ in compound $\mathbf{1}^{24}$; reference $\mathbf{2}$ was prepared for control experiments.

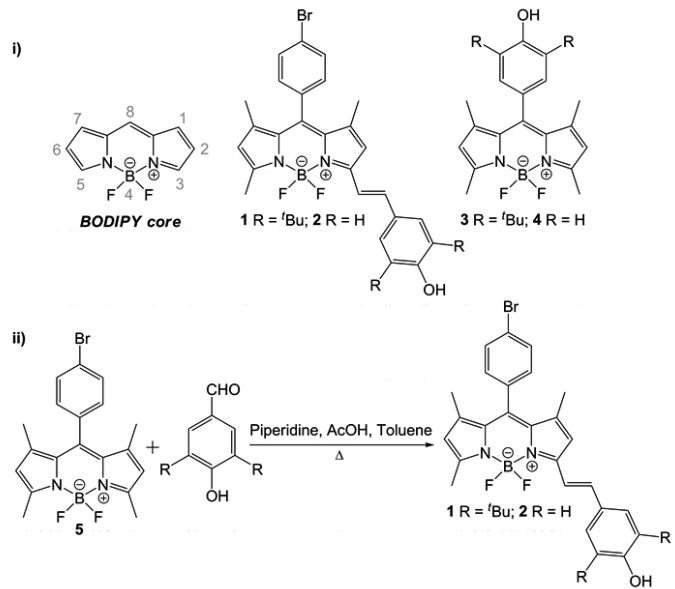

Figure 1. i) The structure of BODIPY derivatives; ii) The synthetic route of compound $\mathbf{1}$ and $\mathbf{2}$.

\section{MATERIAL AND METHODS}

All anions in the tetrabutylammonium salts were purchased from Alfa Aesar Chemical Co., stored in a desiccator under vacuum, and used without further purification. $\mathrm{CH}_{3} \mathrm{CN}$ used in the context was chromatographic pure. Silica gel (mesh 200-300) was used for column chromatography. ${ }^{1} \mathrm{H}$ NMR and ${ }^{13} \mathrm{C}$ NMR spectra were performed on a Varian INOVA $400 \mathrm{MHz}$ spectrometer in $\mathrm{CDCl}_{3}$. ESI-MS studies were carried out using a Waters Micromass ZQ4000 spectrometer. UV-vis titration experiments were made on a Perkin Elmer Lambda 35 spectrometer at $298 \mathrm{~K}$. Fluoremetric titrations were recorded on a Perkin Elmer LS55 spectrometer at $298 \mathrm{~K}$. The affinity constant $K$ was obtained by non-linear least squares calculation method for data fitting.

3-(3,5-di-tert-butyl-4-hydroxyphenyl)ethenyl-4,4-difluoro-8-(4-bromo) phenyl-1,5,7-trimethyl-3a,4a-diaza-4-bora-s-indacene (1)

Compound 5 $(1.00 \mathrm{~g}, 2.19 \mathrm{mmol})^{25}$ and 3,5-di-tert-butyl-4-hydroxybenzalde $(0.51 \mathrm{~g}, 2.19 \mathrm{mmol})$ were refluxed in a mixture of toluene $(70 \mathrm{~mL})$, piperidine $(0.5 \mathrm{~mL})$ and glacetic acid $(0.5 \mathrm{~mL})$. Any water formed was removed by heating in a Dean-Stark apparatus overnight. After completion monitored by TLC, the pink solutions were concentrated to evaporate solvents under reduced pressure. The crude product was purified by column chromatography $\left(\mathrm{CH}_{2} \mathrm{Cl}_{2} /\right.$ Hexane, 1:1) to obtain purple solid 1. Yield 45\%. ${ }^{1} \mathrm{H}$ NMR (400 $\mathrm{MHz}, \mathrm{CDCl}_{3}$ ) d: $1.35\left(\mathrm{~s}, 18 \mathrm{H}, 6 \mathrm{CH}_{3}\right), 1.40\left(\mathrm{~s}, 6 \mathrm{H}, 2 \mathrm{CH}_{3}\right), 2.57\left(\mathrm{~s}, 3 \mathrm{H}, \mathrm{CH}_{3}\right), 5.49(\mathrm{~s}, 1 \mathrm{H}, \mathrm{OH})$, $5.97(\mathrm{~s}, 1 \mathrm{H}, \mathrm{CH}), 6.60(\mathrm{~s}, 1 \mathrm{H}, \mathrm{CH}), 7.20(\mathrm{~d}, J=6.8 \mathrm{~Hz}, 2 \mathrm{H}, 2 \mathrm{ArH}), 7.39(\mathrm{~s}, 2 \mathrm{H}$, $2 \mathrm{ArH}), 7.49\left(\mathrm{~d}, J=16.4 \mathrm{~Hz}, 2 \mathrm{H}\right.$, Vinyl CH) $7.62(\mathrm{~d}, J=6.8 \mathrm{~Hz}, 2 \mathrm{H}, 2 \mathrm{ArH}) .{ }^{13} \mathrm{C}$ NMR (100 MHz, $\left.\mathrm{CDCl}_{3}\right)$ d: 14.1, 14.6, 30.2, 34.3, 108.2, 116.2, 117.9, 121.0, $124.9,127.9,131.2,132.7,134.3,136.3,137.9,138.4,141.4,142.4,154.4$, 154.5 155.3. ESI-MS: (m/z): 619.1.

3-(4-hydroxyphenyl)ethenyl-4,4-difluoro-8-(4-bromo)phenyl-1,5,7trimethyl-3a,4a-diaza-4-bora-s-indacene (2)

It was synthesized according to above procedure with compound $5(1.00 \mathrm{~g}$, $2.19 \mathrm{mmol})$ and 4-hydroxybenzalde $(0.27 \mathrm{~g}, 2.19 \mathrm{mmol})$.Yield $30 \%$. ${ }^{1} \mathrm{H}$ NMR $\left(400 \mathrm{MHz}, \mathrm{CDCl}_{3}\right)$ d: $1.41\left(\mathrm{~s}, 3 \mathrm{H}, \mathrm{CH}_{3}\right), 1.45\left(\mathrm{~s}, 3 \mathrm{H}, \mathrm{CH}_{3}\right), 2.57\left(\mathrm{~s}, 3 \mathrm{H}, \mathrm{CH}_{3}\right)$, $5.19(\mathrm{~s}, 1 \mathrm{H}, \mathrm{OH}), 6.00(\mathrm{~s}, 1 \mathrm{H}, \mathrm{CH}), 6.58(\mathrm{~s}, 1 \mathrm{H}, \mathrm{CH}), 6.82(\mathrm{~d}, J=8 \mathrm{~Hz}, 2 \mathrm{H}$, $2 \mathrm{ArH}), 7.18$ (s, 3H, 2ArH, Vinyl CH), 7.45 (m, 3H, 2ArH, Vinyl CH), 7.63 $(\mathrm{d}, J=8.4 \mathrm{~Hz}, 2 \mathrm{H}, 2 \mathrm{ArH}){ }^{13} \mathrm{C} \mathrm{NMR}\left(100 \mathrm{MHz}, \mathrm{CDCl}_{3}\right) \mathrm{d}: 14.6,116.1,121.1$, 127.1, 129.3, 131.8, 141.7, 143.2, 155,3, 156.3. ESI-MS: (m/z): 508.9.

\section{RESULTS AND DISCUSSION}

\subsection{Spectroscopic characteristics}

Spectroscopic data for sensors $\mathbf{1}$ and $\mathbf{2}$ were gathered in Table 1. Both sensors showed a typical narrow absorption band centered at approximately $570 \mathrm{~nm}$ having about a $70 \mathrm{~nm}$ red shift in relation to the parent BODIPY $5\left(\lambda_{\text {Abs }}=499 \mathrm{~nm}\right)$ in tested solvents. This can be ascribed to the expanded $\pi$-system conjugation by the attachment of phenol fragment to BODIPY. Their high molar absorption coefficients indicated that the long-wavelength absorption spectra were ICT (from phenol to BODIPY) bands. Rhodamine $\mathrm{B}\left(\Phi_{\mathrm{f}}=0.49\right)$ in EtOH was used as a standard to estimate their fluorescence quantum yields $\Phi^{26} .1$ showed a relatively high $\Phi_{\text {r }}$ with respect to 2 , which can be attributed to the large bulky tert-butyl groups hindering $\pi-\pi$ stacking 
of the fluorophore ${ }^{27,28}$. Both $\mathbf{1}$ and $\mathbf{2}$ displayed a strong emission band at about $590 \mathrm{~nm}$ with small Stokes shift. In a short, both sensors exhibited desirable absorption and fluorescence properties without obvious solvent-dependent effect. The introduction of two steric tert-butyl groups substantially affected the fluorescence feature of BODIPY derivatives.

Table 1. Spectroscopic properties of compound $\mathbf{1}$ and $\mathbf{2}$ in various solvents.

\begin{tabular}{|c|c|c|c|c|c|}
\hline Compound & Solvent & $\begin{array}{c}\lambda_{\text {Abs }} \\
(\mathrm{nm})\end{array}$ & $\begin{array}{c}\lambda_{\text {em }} \\
(\mathrm{nm})\end{array}$ & $\Phi_{\mathrm{f}}$ & $\begin{array}{c}\varepsilon^{\times 10^{4}} \\
\left(\mathrm{~L}^{\circ} \mathrm{mol}^{-}\right. \\
\left.{ }^{\cdot} \mathrm{cm}^{-1}\right)\end{array}$ \\
\hline $\mathbf{1}$ & $\mathrm{CH}_{3} \mathrm{CN}$ & 571 & 592 & 0.658 & 9.20 \\
\hline & $\mathrm{EtOH}$ & 576 & 594 & 0.568 & 9.02 \\
\hline & $\mathrm{THF}$ & 577 & 593 & 0.613 & 10.1 \\
\hline & $\mathrm{CH}_{2} \mathrm{Cl}_{2}$ & 578 & 595 & 0.733 & 11.1 \\
\hline & $\mathrm{Cyclohexane}$ & 577 & 594 & 0.668 & 7.95 \\
\hline $\mathbf{2}$ & $\mathrm{CH}_{3} \mathrm{CN}$ & 567 & 585 & 0.526 & 5.21 \\
\hline & $\mathrm{EtOH}$ & 573 & 592 & 0.454 & 5.28 \\
\hline & $\mathrm{THF}$ & 574 & 592 & 0.490 & 3.96 \\
\hline & $\mathrm{CH}_{2} \mathrm{Cl}$ & 571 & 586 & 0.586 & 5.15 \\
\hline & $\mathrm{Cyclohexane}_{2}$ & 570 & 582 & 0.534 & 3.76 \\
\hline
\end{tabular}

$3.2 U V$-vis spectra

The sensing ability of sensor $\mathbf{1}$ with various anions was investigated in $\mathrm{CH}_{3} \mathrm{CN}$ by UV-vis spectroscopy. The titration results of $1\left(1.5 \times 10^{-5} \mathrm{~mol} \cdot \mathrm{L}^{-1}\right)$ with $\mathrm{F}^{-}$were shown in Figure 2. The absorption spectrum of free $\mathbf{1}$ displayed a standard absorption band centered at $571 \mathrm{~nm}$, accompanied by a weak shoulder at $540 \mathrm{~nm}$. With the stepwise addition of $\mathrm{F}^{-}$, the absorption band at $571 \mathrm{~nm}$ decreased and disappeared eventually and two partially overlapped bands emerged at $718 \mathrm{~nm}$ and $757 \mathrm{~nm}(\Delta \lambda=186 \mathrm{~nm})$, respectively. Simultaneously the color of solution changed from pink to light green. A clear isosbestic point at $600 \mathrm{~nm}$ was observed, indicating the formation of $\mathrm{F}^{-}$-sensor complex. Interestingly, the addition of a strong base $\left[\mathrm{Me}_{4} \mathrm{~N}\right] \mathrm{OH}$ to the solution of 1 induced similar changes, which revealed that the interaction between $\mathbf{1}$ and $\mathrm{F}^{-}$was the Brønsted acid-base reaction (deprotonation) in essence. According to the Job plot, sensor 1 interacted with $\mathrm{F}^{-}$in a 1:1 ratio in Figure 2 insert. Consequently, the affinity constant $K$ for $\mathrm{F}^{-}$was determined using the method of non-linear least squares calculation ${ }^{29}$. UV-vis titration experiments of other tested anions were also conducted. In particular, $\mathrm{AcO}-a n d \mathrm{H}_{2} \mathrm{PO}_{4}^{-}$caused similar changes, while the absorption band at $571 \mathrm{~nm}$ would not disappear even upon the excessive addition (Figure S1-S2). Their affinity constants were listed in Table 2 with the order: $\mathrm{F}^{-}>\mathrm{AcO}^{-}>\mathrm{H}_{2} \mathrm{PO}_{4}^{-}$. Such trend may be mainly attributed to the basic properties of three anions. $\mathrm{F}^{-}$itself is a less strong base than $\mathrm{AcO}^{-}$and $\mathrm{H}_{2} \mathrm{PO}_{4}^{-}$, though two $\mathrm{F}^{-}$can from a great basic complex $\mathrm{HF}_{2}{ }^{-}$ which is second only to $\mathrm{OH}^{-30}$. Besides, two tert-butyl groups might tentatively prevent the affinity of $\mathrm{AcO}^{-}$and $\mathrm{H}_{2} \mathrm{PO}_{4}^{-}$to phenol $\mathrm{OH}$ in varying degrees. Adding $\mathrm{Cl}^{-}, \mathrm{Br}, \mathrm{I}^{-}, \mathrm{HSO}_{4}^{-}$and $\mathrm{ClO}_{4}^{-}$induced negligible responses in Figure 3, owing to their slight or no basic properties.

Table 2. Affinity constants for compound $\mathbf{1}$ and $\mathbf{2}$ with putative anions as determined from UV-vis at $571 \mathrm{~nm}$ and $567 \mathrm{~nm}$ in $\mathrm{CH}_{3} \mathrm{CN}$, respectively.

\begin{tabular}{|c|c|c|}
\hline Anion & $K(\mathbf{1})$ & $K(\mathbf{2})$ \\
\hline $\mathrm{F}^{-}$ & $2.72 \times 10^{4}$ & $2.17 \times 10^{4}$ \\
\hline $\mathrm{AcO}^{-}$ & $8.13 \times 10^{3}$ & $3.42 \times 10^{3}$ \\
\hline $\mathrm{H}_{2} \mathrm{PO}_{4}^{-}$ & $3.79 \times 10^{3}$ & $1.11 \times 10^{3}$ \\
\hline
\end{tabular}

Interestingly, in our previous work, sensor 3 can selectively recognize $\mathrm{F}^{-}$over $\mathrm{AcO}^{-}$and $\mathrm{H}_{2} \mathrm{PO}_{4}^{-}$owing to the fitness in the acidity of $\mathrm{OH}$ group with strong basic $\mathrm{F}^{-}$. To account for such different sensing behaviors, their molecular configurations had to be considered. $\mathrm{C}(8)$-phenol ring and BODIPY plane adopted a perpendicular configuration in $\mathbf{3}$, but in $\mathbf{1}$ both fragments might fix a coplanar arrangement in favor of the p-system conjugation in overall molecule. Furthermore, BODIPY core could serve as an electron-withdrawing group, which increased the acidity of phenolic $\mathrm{OH}$ proton in $\mathbf{1}$. This acidity enhancement can be also reflected by their chemical shifts of $\mathrm{OH}$ proton in ${ }^{1} \mathrm{H}$ NMR. Under the same experimental condition, the $\mathrm{OH}$ proton signal of $\mathbf{1}$ appeared at $5.49 \mathrm{ppm}$ in the more downfield than that of $\mathbf{3}$ at $5.37 \mathrm{ppm}$. On this basis, $\mathbf{1}$ is relatively more acidic than $\mathbf{3}$ and undergoes deprotonation in the presence of two less basic anions $\mathrm{AcO}^{-}$and $\mathrm{H}_{2} \mathrm{PO}_{4}^{-}$except $\mathrm{F}^{-}$. Apart from the structural influence, we wonder if the steric hindrance of two tert-butyl groups makes substantial contributions to coordinating tested anions. Control experiments were resultantly carried out using compound $\mathbf{2}$ without tert-butyl groups.

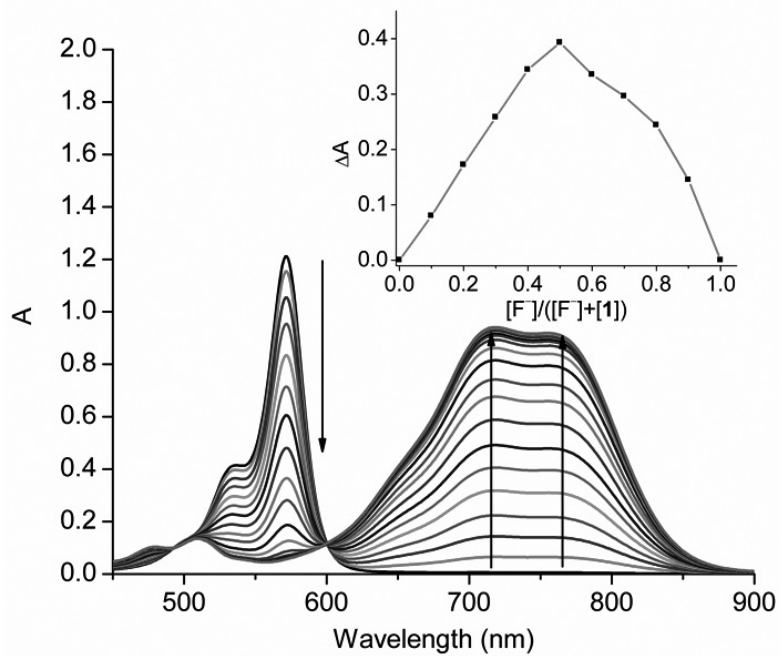

Figure 2. UV-vis titration of compound $1\left(1.5 \times 10^{-5} \mathrm{~mol} \cdot \mathrm{L}^{-1}\right)$ upon the addition of $\mathrm{F}^{-1}\left(0 \sim 2.7 \times 10^{-5} \mathrm{~mol} \cdot \mathrm{L}^{-1}\right)$ in $\mathrm{CH}_{3} \mathrm{CN}$. Insert: A job plot of 1 with $\mathrm{F}^{-1}$.

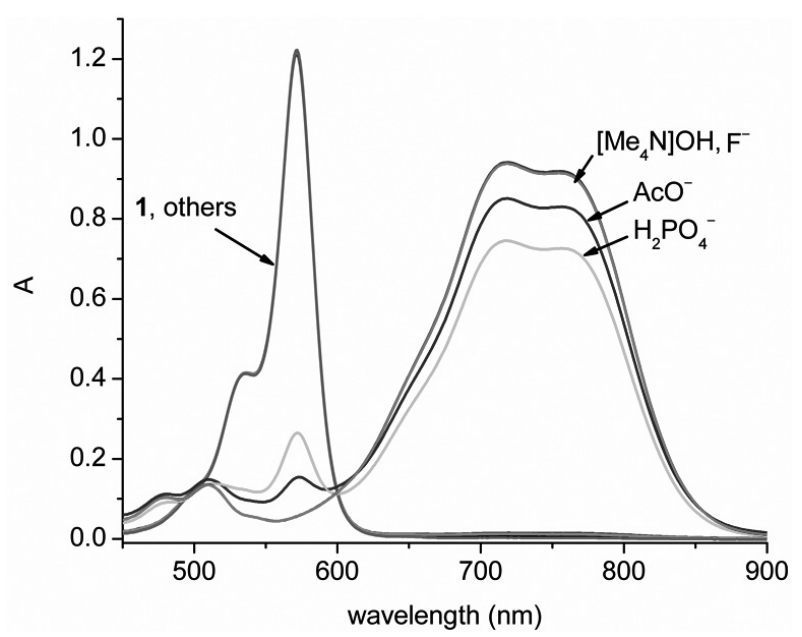

Figure 3. UV-vis spectra of compound $1\left(1.5 \times 10^{-5} \mathrm{~mol} \cdot \mathrm{L}^{-1}\right)$ upon the addition of respective anions $\left(1.6 \times 10^{-4} \mathrm{~mol} \cdot \mathrm{L}^{-1}\right)$ in $\mathrm{CH}_{3} \mathrm{CN}$.

As shown in Figure 4, adding $\mathrm{F}^{-}, \mathrm{AcO}^{-}$or $\mathrm{H}_{2} \mathrm{PO}_{4}^{-}$to the solution of 2 led to a $133 \mathrm{~nm}$ red-shift absorption band at $700 \mathrm{~nm}$. This large red shifts are attributable to the removal of phenol $\mathrm{OH}$ proton, which can be also identified by the addition of $\left[\mathrm{Me}_{4} \mathrm{~N}\right] \mathrm{OH}$. Their affinity constants $K$ were calculated using UV-vis titrations (Figure S3-S5) and listed in Table 2. Compared with 1,2 suggested only one absorption peak and the same order of magnitude in affinity constants yet slight smaller values. First, this new emerging band corresponds to one peak at $718 \mathrm{~nm}$ for 1 -anion complex, which results from ICT process from phenolate to BODIPY core. After deprontonation, an increase of the electron density on oxygen would cause delocalization with the electron-withdrawing BODIPY unit. Thus, the electrons are rearranged and the p-electron delocalization extends in the whole molecule leading to an obvious red shift ${ }^{31}$. In the process of delocalization, two electron-rich tert-butyl groups would help delocalize and form allotropic $1 \mathbf{b}$ in Figure $5^{32-34}$. It can be 
speculated that the other novel band at $757 \mathrm{~nm}$ can be assigned to the formation 1b. On the contrary, 2 cannot effectively develop an allotropic structure due to lack of tert-butyl groups. Second, the anion binding capacity of $\mathbf{1}$ and $\mathbf{2}$ suggests only slight difference, which indicates two tert-butyl groups could not reveal the significant steric effect for $\mathrm{AcO}^{-}$and $\mathrm{H}_{2} \mathrm{PO}_{4}^{-}$. Without hindrance, $K$ values of 2 also followed the trend: $\mathrm{F}^{-}>\mathrm{AcO}^{-}>\mathrm{H}_{2} \mathrm{PO}_{4}^{-}$, owing to the basic properties of anions ${ }^{30}$. For special anion, $K(\mathbf{1})$ is a little bigger than $K(\mathbf{2})$ which indicates that the acidity of $\mathrm{OH}$ in $\mathbf{1}$ is slight greater than in $\mathbf{2}$. This can be confirmed by the $\mathrm{OH}$ proton signal of $\mathbf{1}$ and $\mathbf{2}$, refer to as $5.49 \mathrm{ppm}$ and 5.19 $\mathrm{ppm}$, in ${ }^{1} \mathrm{H}$ NMR. Namely, interaction of anions with BODIPY-phenol sensors primarily rely on not the hindrance of tert-butyl groups, but the acidity of phenol $\mathrm{OH}$ and the basicity of anions.

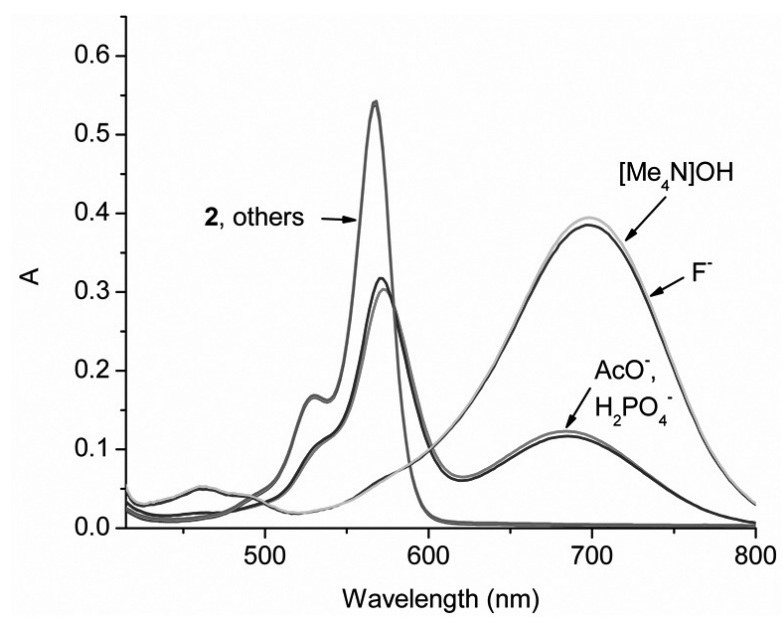

Figure 4. UV-vis spectra of compound $2\left(1.5 \times 10^{-5} \mathrm{~mol} \cdot \mathrm{L}^{-1}\right)$ upon the addition of 10 equiv of respective anions in $\mathrm{CH}_{3} \mathrm{CN}$.

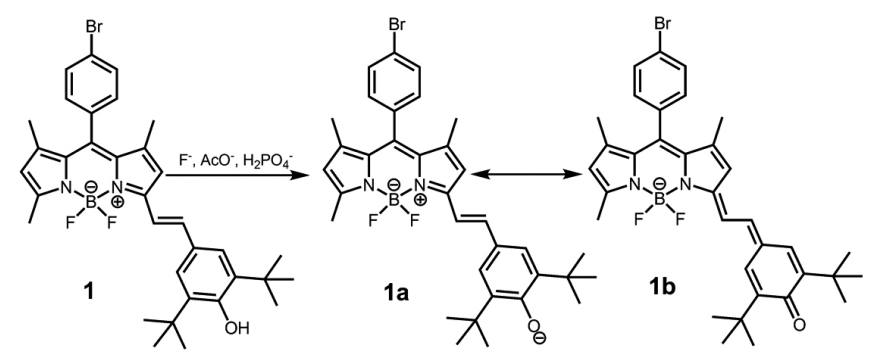

Figure 5. Proposed sensing mechanism of compound $\mathbf{1}$ with anions.

\subsection{Fluorescence spectra}

The responses of $\mathbf{1}$ toward tested anions were also investigated by fluorescence technology in $\mathrm{CH}_{3} \mathrm{CN}$. Just as Figure 6 showed, the fluorescence intensity at $592 \mathrm{~nm}$ diminished in pace with the addition of $\mathrm{F}^{-}$without any obvious changes in the emission wavelength. Similar changes was also observed upon the stepwise addition of $\mathrm{AcO}^{-}$and $\mathrm{H}_{2} \mathrm{PO}_{4}^{-}$(Figure $\mathrm{S} 6$ and S7), respectively. Such quenching can be attributable to the occurrence of ICT quenching the exited state of BODIPY moiety by the phenolate salt ${ }^{22}$. It was found that 1 demonstrated fluorescence quench in varying degrees, which was 97 -fold for $\mathrm{F}^{-}, 10$-fold for $\mathrm{AcO}^{-}$and 5 -fold for $\mathrm{H}_{2} \mathrm{PO}_{4}^{-}$in Figure 7. This trend is in agreement with those affinity constants obtained using UV-vis analyses. Besides, compared with 2, 1 revealed significant quenching for $\mathrm{F}^{-}$ and insufficient quenching for $\mathrm{AcO}^{-}$and $\mathrm{H}_{2} \mathrm{PO}_{4}^{-}$(Figure S8-S10), because of their different acidity of phenol $\mathrm{OH}$ and their stability of allotropic structures. Nevertheless there was no significant quenching of both sensors for other anions.

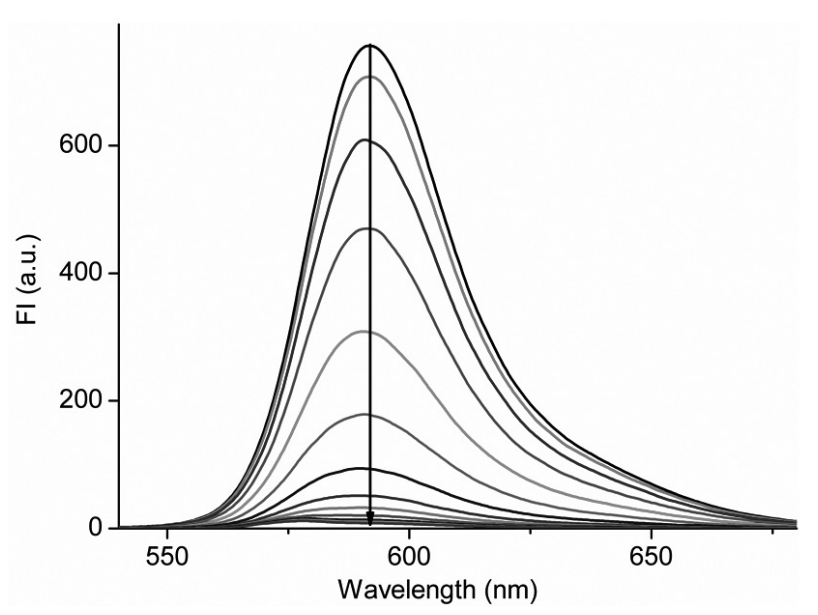

Figure 6. Fluorescence spectra of compound $1\left(1.5 \times 10^{-6} \mathrm{~mol} \cdot \mathrm{L}^{-1}\right)$ upon the addition of $\mathrm{F}^{-1}\left(0 \sim 4.8 \times 10^{-6} \mathrm{~mol} \cdot \mathrm{L}^{-1}\right)$ in $\mathrm{CH}_{3} \mathrm{CN}$. Excitation was at $570 \mathrm{~nm}$.

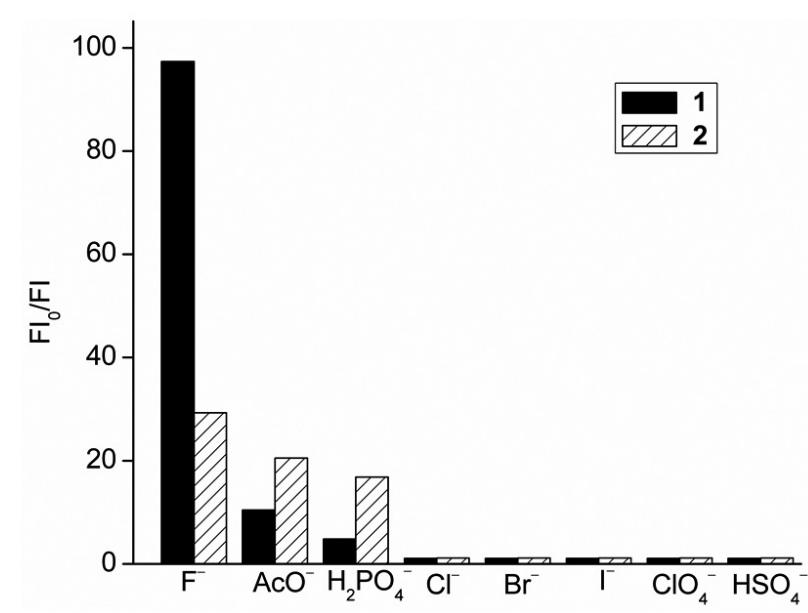

Figure 7. Changes intensity of the emission band at $592 \mathrm{~nm}$ in compound 1 $\left(1.5 \times 10^{-6} \mathrm{~mol} \cdot \mathrm{L}^{-1}\right)$ and at $585 \mathrm{~nm}$ in compound $2\left(1.5 \times 10^{-6} \mathrm{~mol} \cdot \mathrm{L}^{-1}\right)$ in presence of 10 equiv of anions tested in $\mathrm{CH}_{3} \mathrm{CN}$.

\section{CONCLUSION}

In conclusion, an optical anion sensor $\mathbf{1}$ incorporating di-tert-butyl phenol unit at 3-position of BODIPY was successfully prepared, which can selectively recognize three basic anions based on the deprotonation mechanism. Addition of $\mathrm{F}^{-}, \mathrm{AcO}^{-}$or $\mathrm{H}_{2} \mathrm{PO}_{4}^{-}$elicited two novel partially overlapped bands in UV-vis spectra and fluorescence quenching in varying degrees, owing to ICT process from phenolate salt to BODIPY core. These behaviors are closely related to the acidic tendencies of the sensor $\mathbf{1}$ and to the basic properties of the anion. Although two bulky tert-butyl groups could not impede the contiguity of large anions with phenol $\mathrm{OH}$, they can facilitate the formation of allotropic structure after deprotonation. Hence, the acidity of anion binding site should be delicately tuned by introducing multifunctional groups in order to fit the targeted basic anion.

\section{ACKNOWLEDGEMENT}

This work was supported by the scientific research foundation of Sichuan University of science and Engineering (2012RC02) and Key Laboratories of Fine Chemicals and Surfactants in Sichuan Provincial Universities (2014JXY01)

\section{REFERENCES}

1. P.A. Gale, N. Busschaert, C.J. Haynes, L.E. Karagiannidis, I.L. Kirby, Chem. Soc. Rev. 43, 205, (2014) 
2. L.E. Santos-Figueroa, M.E. Moragues, E. Climent, A. Agostini, R. Martínez-Máñez, F. Sancenón, Chem. Soc. Rev. 42, 3849, (2013).

3. R. Vilar Recognition of Anions, Berlin Heidelberg, Springer-Verlag, (2008)

4. K. Bowman-James, Acc. Chem. Res. 38, 671, (2005)

5. C.R. Bondy, S.J. Loeb, Coord. Chem. Rev. 240, 77, (2003)

6. C. Suksai, T. Tuntulani, Coord. Chem. Rev. 32, 192, (2003)

7. R.Y. Liu, Y. Gao, Q.B. Zhang, X.D. Yang, X.W. Lu, Z.Y. Ke, W.Q. Zhou, J.Q. Qu, New. J. Chem. 38, 2941, (2014)

8. U. Fegade, S. Sahoo, A. Singh, P. Mahulikar, S. Attarde, N. Singh, A. Kuwar, RSC. Adv. 4, 15288, (2014).

9. X.F. Shang, H.W. Wu, S.Y. Jia, J. Han, Y. Liu, Z. Yin, X.J. Qin, J.L. Zhang, X.F. Xu, J. Chil. Chem. Soc. 58, 1862, (2013)

10. D.H. Lee, J. H. Im, S.U. Son, Y.K. Chung, J.I. Hong, J. Acs. Chem. Soc. 125, 7752, (2003)

11. D. H. Lee, H. Y. Lee, K. H. Lee, J. I. Hong, Chem. Commun. 13, 1188, (2001)

12. K. H. Lee, H. Y. Lee, D. H. Lee, J. I. Hong, Tetrahedron. Lett. 42, 5447, (2001)

13. K. Tsubaki, M. Nuruzzaman, T. Kusumoto, N. Hayashi, W. B. Gui, K. Fuji, Org. Lett. 3, 4071, (2001)

14. H. Lu, J. Mack, Y.C. Yang, Z. Shen, Chem. Soc. Rev. DOI: 10.1039/ C4CS00030G, (2014)

15. N. Boens, V. Leen, W. Dehaen, Chem. Soc. Rev. 41, 1130, (2012)

16. G. Ulrich, R. Ziessel, A. Harriman, Angew. Chem. Int. Ed. 47, 1184, (2008)

17. A. Loudet, K. Burgess, Chem. Rev. 107, 4891, (2007)
18. R. Ziessel, G. Ulrich, A. Harriman, New, J. Chem. 31, 496, (2007)

19. M. Baruah, W.W. Qin, N. Basarić, W.M. Borggraeve, N. Boens, J. Org. Chem. 70, 4152, (2005)

20. T. Gareis, C. Huber, O. Wolfbeis, J. Daub, Chem. Commun. 18, 1717, (1997)

21. Y.J. Lv, J. Xu, Y. Guo, S.J. Shao, Sci. China. Chem. 54, 797, (2011)

22. O.A. Bozdemir, F. Sozmen, O. Buyukcakir, R. Guliyev, Y. Cakmak, E.U. Akkaya, Org. Lett. 12, 1400, (2010)

23. V. Thiagarajan, P. Ramamurthy, D. Thirumalaim V.T. Ramakrishan, Org. Lett. 7, 657, (2005)

24. C.H. Rochester, B. Rossall, Trans. Faraday. Soc. 65, 992, (1969)

25. M. Kollmannsberger, K, Rurack, U. Resch-Genger, J. Daub, J. Phys. Chem. A. 102, 10211, (1998)

26. N. Almonasy, M. Nepraš, S. Hyková, A. Lyčka, J. Čermák, M. Dvořák, M. Michl, Dyes. Pigment. 82, 164, (2009)

27. T. Ozdemir, S. Atilgan, I. Kutuk, L.T. Yildirim, A. Tulek, M. Bayindir, E. U. Akkaya, Org. Lett. 11, 2105, (2009)

28. C.J. Jiao, K.W. Huang, J.S. Wu, Org. Lett. 13, 632, (2011)

29. J. Bourson, J. Pouget, B. Valeur, J. Phys. Chem. 97, 4552, (1993)

30. V. Amendola, D. Esteban-Gómez, L. Fabbrizzi, A.M. Licchelli, Acc. Chem. Res. 39, 343, (2006)

31. V. Lakshmi, M. Ravikanth, J. Mater. Chem. C. 2, 5576, (2014)

32. A. Shundo, J.P. Hill, K. Ariga, Chem. Eur. J. 15, 2486, (2009)

33. T. V. Goud, A. Tutar, J. F. Biellmann, Tetrahedron. 62, 5084, (2006)

34. S. Ito, S. Kikuchi, H. Kobayashi, N. Morita, T. Asao, J. Org. Chem. 62, 2423, (1997) 